\title{
血栓形成と血流の変化の測定
}

\author{
佐 藤 正 明*, 大 島 宣 雄*
}

\section{Thrombus Formation and Blood Flow Dynamics in Microvessels}

\author{
Masaaki SATO and Norio OSHIMA
}

\author{
Key words : light/dye reaction, microcirculation, platelet thrombus, blood flow \\ dynamics, wall shear rate, active oxygen
}

\section{はじめに}

傷害を受けた血管内皮細胞に血小板が粘着 し，血栓として成長していく過程は，多くの因 子が相互に作用し合って複雑な経過を構成して いる. 本講座では，これらの因子の中で特に血 流の動態に焦点を当て, 血小板の血栓形成の開 始から成長に至る過程と血流動態との関係につ いて，著者らの研究をもとに概説する，血栓の 形成に血流因子が重要な役割を演じていること は, 古くVirchow の時代から指摘されている ところである1).しかしながら，流れの影響一 つとってみても，速い流れによって血小板自身 は活性化し粘着は促進する方向に向かうのに対 し, 一方では粘着を阻害あるいは形成された血 栓を剝離して血栓の成長を抑制し，相反する二 つの作用をみせる。このために，血流の及ぼす 影響は一見複雑な様相を呈することになる。

ここでは, 対象を微小循環系の血管に絞り， 著者らの開発した血小板血栓形成モデル233) を 中心に話を進め, 血栓形成に対する血流のもつ 意義の一端を明らかにする。

\section{血栓形成モデル}

著者らは, 光と蛍光色素の反応によって微小 血管内に血小板血栓を作製する方法を新たに見
いだし2)3)，血栓形成モデルとして確立した。 以下にその方法を要約する。

使用するシステムは, Fig. 1 に模式的に示す 蛍光生体顕微鏡を基本とした装置である。これ までは主に腸間膜の微小血管床を対象としてい るが，微小血管が観察可能な部位であればいず れの血管にも応用可能である。

まず, 蛍光色素を励起するための光を落射光 学系を通して, 目的とする微小血管に照射す る. 光の波長は使用する色素によって異なり, 著者らが通常使用しているフルオレセインナト リウム（Fl $\mathrm{Na}$ : sodium fluorescein）の場合 は，蛍光顕微鏡に備え付けられた FITC ある いは B 励起による波長 400〜 $500 \mathrm{~nm}$ の青色の 光である. 続いて, 外頝静脈へのカニューレを 通して，一定濃度の蛍光色素を注入する。こう すると, 光の照射領域に蛍光色素が到達し, お 互いの反応によって内皮細胞が傷害を受け，血 小板の内皮細胞への粘着, 凝集過程を顕微鏡下 に観察することができる. 光の照射領域を直径 $130 \mu \mathrm{m}$ に絞り, 腸間膜の内径 $62 \mu \mathrm{m}$ の細静脈 内に形成させた血栓の様子を Fig. 2 に示す. この血栓の成長の過程すなわち血栓の形成開始 および成長の速度は, 照射した光の強度並びに 蛍光色素の濃度に依存しており, 光の強度が強 く蛍光色素の濃度が高いほど血栓はできやすく

* 筑波大学基礎医学系医工学 (つくば市天王台 1-1-1)：Tsukuba University, 1-1-1 Ten-nodai, Tsukuba Ibaraki 305, Japan 


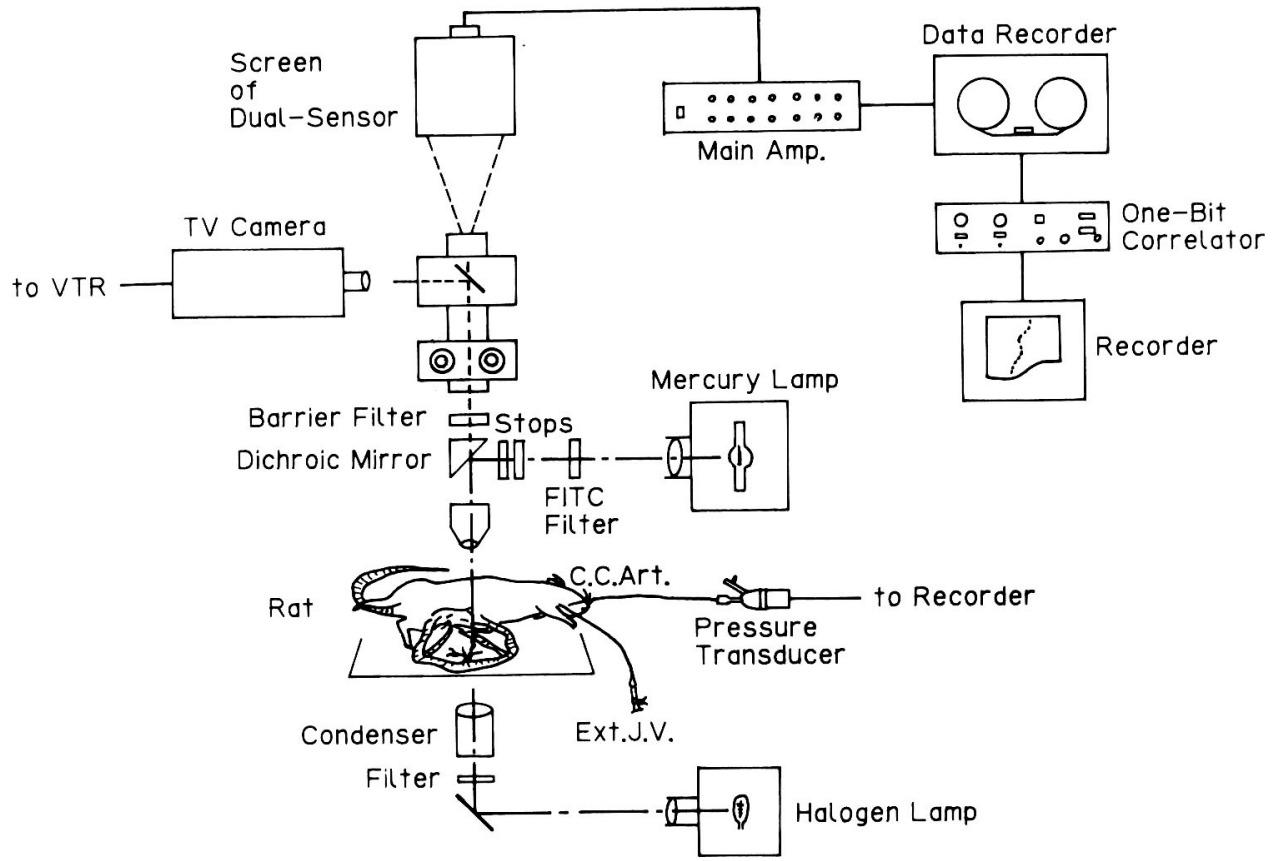

Fig. 1 Schematic diagram of experimental apparatus. Screen of 10-channel dual-sensor is set above intravital microscope.

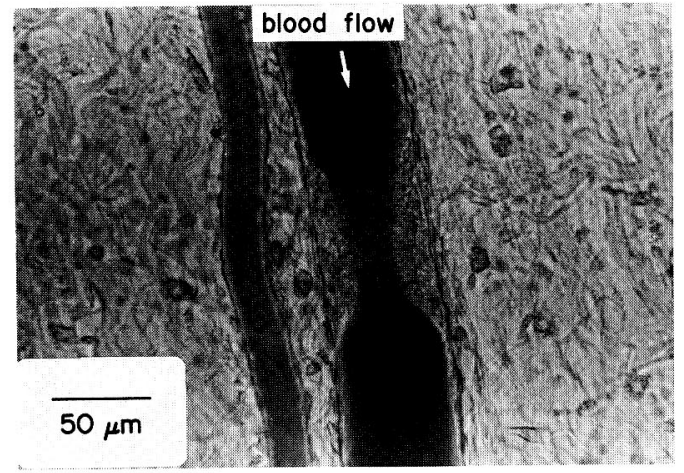

Fig. 2 Photomicrograph of microthrombus induced in a venule of $62 \mu \mathrm{m}$ in diameter.

なる2).

現時点では, 本血栓モデルの形成機序の詳細 は不明であるが，著者らは以下のように考えて いる.一般的には，光と色素の反応によって活 性酸素 (特に一重項酸素) が発生することはよ く知られており，この活性酸素が内皮細胞の膜 に微小な傷害を引き起こすことが想定される. しかしながら，著者らの実験では活性酸素の一 種であるスーパーオキサイドの除去剤の SOD (superoxide dismutase) の投与により，血栓 の形成と成長が有意に抑制されることがわかっ ている4)。また, Rosenblum ら5) は, DMSO (dimethyl sulfoxide) によって，この血小板の 凝集が有意に抑制されるとして，活性酸素のう ちのハイドロキシルラジカルの重要性を指摘し ている.このように, 蛍光色素と光の反応によ って形成される血小板血栓には何らかの形で活 性酸素が関与しているものと考えられる。

\section{微小循環系における血流速度の測定}

微小循環系における血流速度の測定に当たっ ては，太い血管系で一般に使用されている装置 と違って，特別な装置が用いられる．著者らの 使用している方法は，Fig. 1 にその装置の模 式図を示すデュアル・センサ法（dual-sensor method）である. 装置の詳細を示したのが, Fig. 3 である ${ }^{6}$. 原理的には, 赤血球をマーカ として，2つのサンプリング点間を経過するの に要する時間を統計的に計測する方法に基づい ている．実際の計測においては，顕微鏡によっ て観察した像を Fig. 3 に示すスクリーン上に 


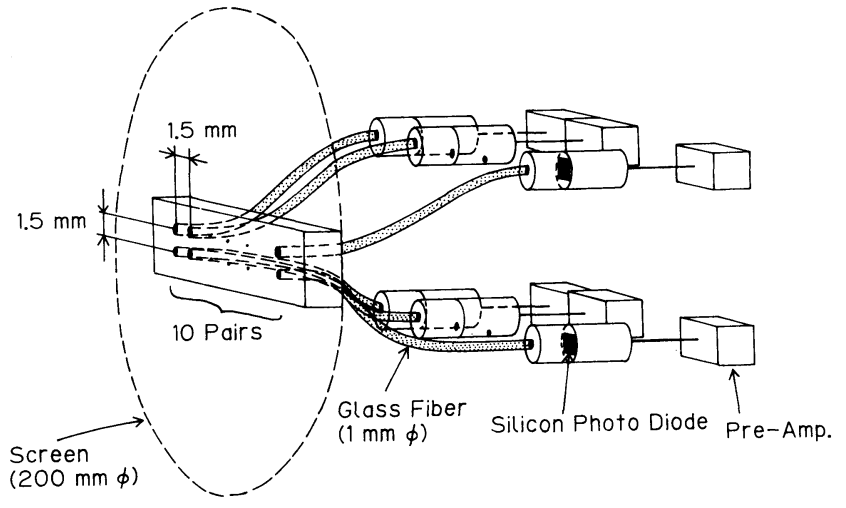

Fig. 3 Schematic diagram of a projection screen of the dual-sensor equipment.

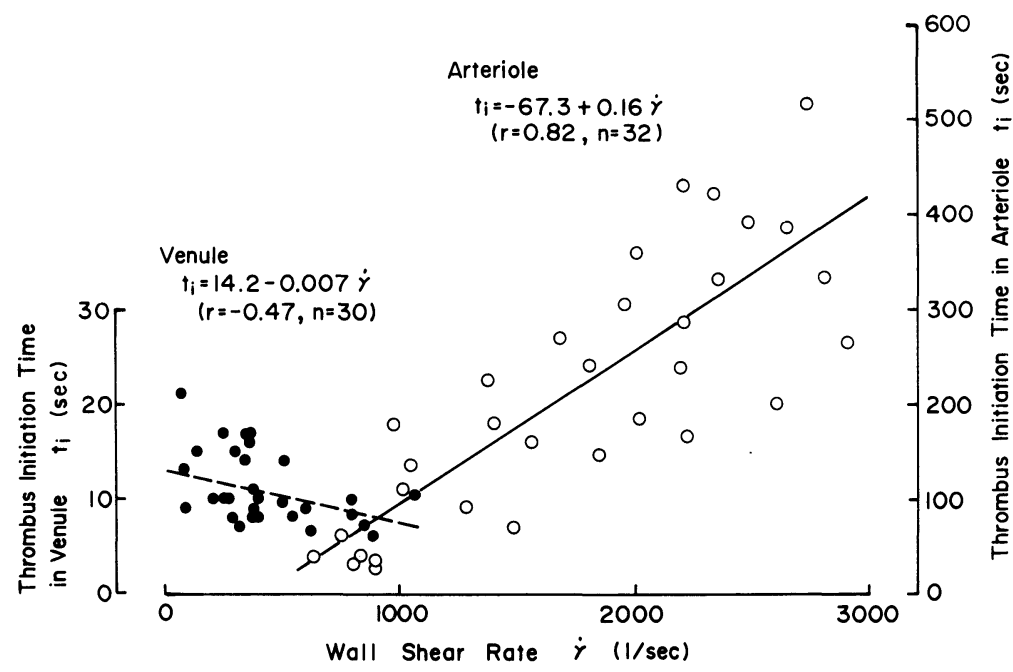

Fig. 4 Effect of wall shear rate on thrombus initiation time, $t_{1}$, in venules and arterioles. $r$, Correlation coefficient; $\mathrm{n}$, number of data points (on rats).

投影し，測定の対象となる微小血管内の赤血球 による光学的な明暗の変化を，スクリーン上に セットした 2 つ光センサによってとらえる. 続いて，この 2 点間の信号の遅れ時間を相互相 関計7)によって計測し，血流速度に換算する ことになる.Fig. 3 に示す装置は，これを血 管の半径方向に沿って，同時に 10 点の計測が 可能なように，著者らの研究室で開発したもの である。

\section{血栓形成に及ぼす血流動態の影響}

血小板血栓が形成される初期の過程では，血 小板と内皮細胞の局所における相互作用が重要 になってくる．この点から，血管内皮近傍の血 液の流れの状態を示すパラメータとして，次式 によって表される壁ずり速度（wall shear rate， $\dot{\gamma}$ ) を用いて，血栓形成開始の状態を整 理した.

$$
\dot{\gamma}=4 \overline{\mathrm{v}} / \mathrm{r}
$$

ここで， $\overline{\mathrm{v}}$ は血液の平均流速， $\mathrm{r}$ は血管の半径 である。すなわち，このパラメー夕は血液が内 皮を擦る程度を表すものであって，流体力学的 には壁近傍の血液の流れの速度勾配を意味して いる．血栓のできやすさを表すパラメータとし ては，正確かつ容易に測定可能であることか ら，一定濃度の蛍光色素を投与し，一定の光強 度の励起光を照射した際に，目的とする微小血 管の内皮に血小板が粘着し始める時間（ $t_{1} ）$ を 採った。ラット腸間膜の細動脈および細静脈に 対して計測を行った結果を Fig. 4 に示す8). 細静脈では全体的に血栓形成時間が早く，しか も壁ずり速度が速い程血栓形成が早く生ずると 


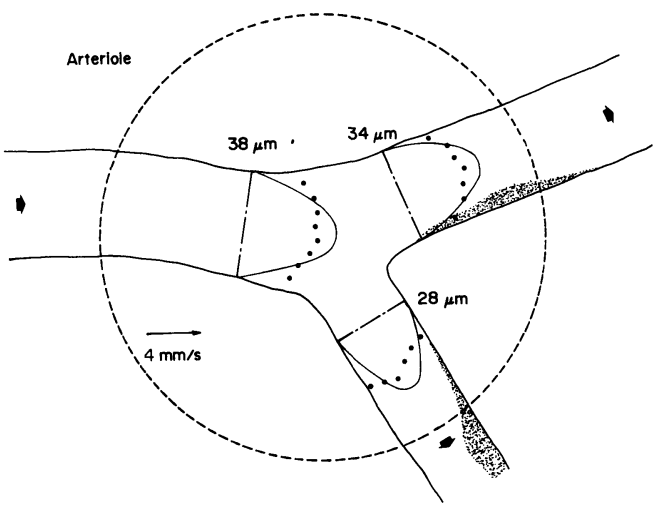

Fig. 5 Blood flow velocity profiles and thrombus initiation sites at an arteriolar bifurcation. Dots represent velocity measured by dual-sensor method. Parabolic solid lines are velocity profiles corrected by method of Baker and Wayland ${ }^{9)}$ on assumption of an ideal Poiseulle flow in a straight tube. These parabolic solid lines give reference information on distortion of measured velocity profiles. Short arrows in microvessels indicate blood flow direction. Length of long arrow expresses magnitude of velocity written below; distance from chain line to dots and parabolic solid lines shows magnitude of velocity in microvessels. Broken circular line is area irradiated by excitation light. Numbers beside chain lines are internal diameters of microvessels.

いう結果となった。これに対して，血液の流れ る速度が速い細動脈においては，壁ずり速度が 速い場合には血栓の形成は極端に遅くなってく ることが明らかである. 図中に示す直線の相関 係数（r）の值は統計学的に有意である。この 結果から，著者らのモデルのように内皮細胞が 軽度の傷害を受けていた場合，壁ずり速度が大 体 700〜1,000 $\mathrm{sec}^{-1}$ の領域を境にして血小板 と内皮細胞の相互作用の様子が異なるようであ る.すなわち，傷害を受けた内皮細胞に血小板 が粘着する過程が確率的に起るとする．この場 合, 血液の流れる速度が遅いと単位時間当りに 血漿に浮かんで運ばれてくる血小板の数も少な く, したがって内皮細胞に粘着する血小板の数 も少なくなって, 血栓形成開始時間が遅くなる ことになる，これに対して，細動脈のように血

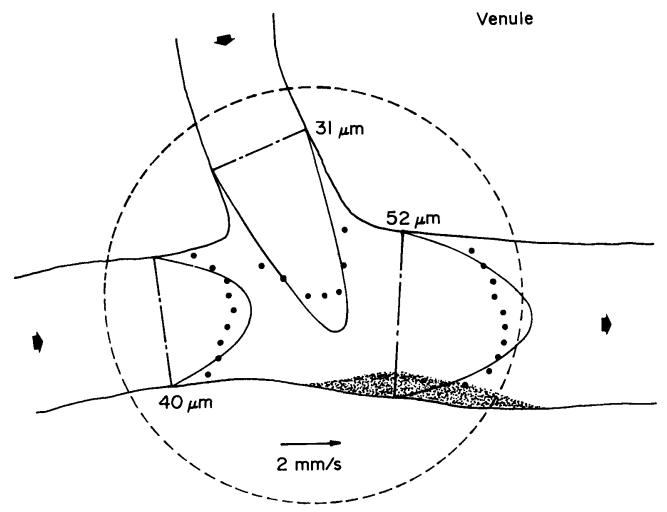

Fig. 6 Blood flow velocity profiles and thrombus initiation sites at a venular confluence. Explanations in the panel are the same as those in Fig. 5.

液の流れる速度が速くなった状態では, 上述の 過程のように多くの血小板が流れてきて内皮細 胞に粘着する数が増える確率は大きくなるが, たとえ血小板が内皮細胞に粘着しても, 高い壁 ずり速度によって剥がされる力も強くなり, 粘 着力が弱い場合には血栓の形成に至らないとい うことになる。このようにして，血液の流れの 立場からみれば血栓形成にとって最適（悪?） の状態がありそうである。

血液の流れの状態が複雑な細動脈の分岐部お よび細静脈の合流部において, 同様の実験を行 った結果を Figs. 5, 6 に示す8). この実験で は, まず最初に, 分岐部および合流部の近傍に おける血流速度の分布を Fig. 3 に示した測定 装置を用いて計測した。その結果は図中にドッ トとして示されている. 続いて, 図の破線で示 す円の領域に励起光を照射し, 分岐部および合 流部にある内皮細胞に一様に傷害を加え, 血小 板血栓のでき始める部位を観察した. Fig. 5 に示す細動脈の分岐部の例では, 血栓は分岐部 の血管の内側に形成されている。これは, 図中 のドットマークで示す血流速度分布から明らか なように，いずれも速度勾配の小さいいわゆる 低壁ずり速度側に対応している.一方, Fig. 6 に示す細静脈の合流部の例では, 血栓は合流直 後の外側に形成している，血栓形成部における 速度分布をみると, 速度勾配の大きい高ずり速 度側に血栓ができ始めていることがわかる。こ 


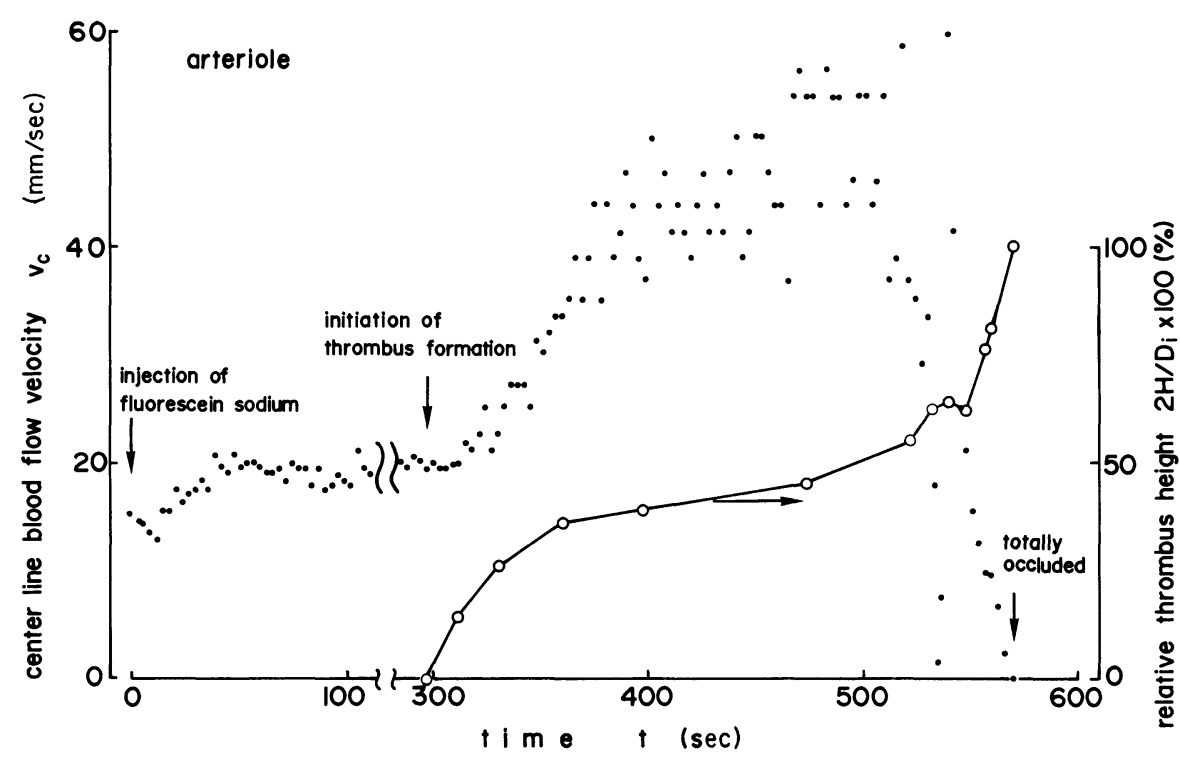

Fig. 7 Time course for changes in the center line blood flow velocity and relative thrombus height in arteriole with a diameter of $42 \mu \mathrm{m}$.

の分岐部および合流部の例では流れが複雑なた め, 計算によって正確に壁ずり速度を求めるこ とは難しく，相対的に壁ずり速度が高いあるい は低いという表現をした。これらの結果を Fig. 4 の結果と合わせて考えると, 相対的に は細静脈においては壁ずり速度の高い側に血小 板の血栓はできやすいということがいえそうで ある、筆者らの実験においても，もちろん例外 が観察された場合もあった ${ }^{8)}$.ただし，この場 合には細動脈での血流速度がかなり遅く, 細静 脈での血流速度が速い例であった。

これまでは，血栓の形成開始の状態に焦点を 当ててみてきたが, この血栓モデルでは血栓の 成長に対する血流動態の影響も観察できる ${ }^{8}$. すなわち, Fig. 2 に示すように血栓がある程 度成長した段階で励起光の照射を中断すると血 栓の成長を止めることができる，この状態で血 栓によって囲まれた最狭部の血流速度を計測 し, その後再び励起光を照射して血栓の体積の 増加速度あるいは血栓の半径方向への成長速度 との関係を調べるわけである。その結果, 血栓 近傍での壁ずり速度が $1,500 〜 2,000 \mathrm{sec}^{-1}$ 辺 りで血栓がもっとも成長しやすく前述の血 小板の内皮細胞への粘着過程に対する壁ずり速 度の効果が，この場合にも当てはまりそうであ
る.ただし，血小板どうしの凝集力に依存し て, 血栓が成長しやすい壁ずり速度は異なるこ とが予想される。

\section{血栓の成長に伴う血流動態の変化}

著者らの血栓モデルでは，時間とともに血栓 の成長していく過程をテレビ画面を通して観察 することができる，その間，血栓の成長に伴っ て血栓部位における血流動態も変化していると 思われる．そこで, 血栓の成長の様子を観察し ながら, Fig. 2 における血栓部の最狭部の流 速をデュアル・センサ法を用いて計測した。得 られた結果の 1 例を Fig. 7 に示す ${ }^{10)}$. 内径 42 $\mu \mathrm{m}$ の細動脈内の中心部流速 $\left(\mathrm{v}_{\mathrm{c}}\right)$ が, 血栓の 成長に伴って時間とともに変化していく様子を ドットマークで表している。一方，血栓の成長 の様子は，血管内径に対する血栓の相対的な高 さとして実線によって示されている.細動脈の 場合には, 蛍光色素投与から血栓形成開始まで の時間が長く, 血流速度はある程度の変動はあ るもののほぼ一定した状態を保っている。しか しながら，血栓形成開始によって血流速度は上 昇し始め, 血栓の成長による血液流路の狭小に 伴って血流速度は急激に増加している様子がよ くわかる，血栓がある程度の高さに達すると血 
栓の成長と流れによる血栓の剥離がバランスす る領域があり，この辺りで測定された血流速度 は飛翔する微小血栓の影響もあって大きく変動 している。このような変動はもちろん細静脈に おいても観察されるが, Fig. 7 に示す細動脈 ではより激しいようである。ところが，血栓の 相対的高さが約 $65 \%$ の辺りまで達すると血流 速度は急激に低下して直ちに血流停止に至って しまう。この間に血小板は赤血球を伴って血栓 を急激に成長させる。

血栓の相対的な高さを血管の断面積に対する 狭窄率として計算し直し, 血流速度が急激に低 下する時の值を求めた ${ }^{10)}$. すると, 内径 $30 \sim 80 \mu \mathrm{m}$ の細静脈および内径 $45 \mu \mathrm{m}$ 程度の 細動脈のいずれの血管においても断面狭窄率は $70 \sim 90 \%$ の範囲に入り平均値はほほ $85 \%$ の値 であった。

血栓の成長に伴い, 狭窄部における中心流速 が増加してくる点については前述したとおりで ある。そこで, 流路の断面積と中心流速から血 流量を計算し, 血栓の成長との関係を検討し た。その結果，血栓が成長していく過程におい ても血流量は一定に保たれるように変化してお り,この状態は Fig. 7 で示した血流速度の急 激な低下が始まるまで続いていることが明らか となった ${ }^{10)}$.

\section{おわりに}

微小循環系における血小板血栓モデルに基づ いて，血管内の血流動態が血栓の形成，成長に どのように影響しているかについて概要を述べ た。さらに，血栓の成長過程における血流動態 の変化についても，血流量を一定に保つように 末梢レベルで調節が行われていることを示唆す る結果を示した。このような結果は，あくまで も著者らの血栓モデルを用いた場合の結果であ る.しかしながら，血小板の内皮細胞への粘着 から始まる一連の血栓形成過程は，必ずしも内 皮細胞の剝離といった激しい現象を伴わなくて も起り得る現象であり，本モデルはその意味に おいては生体内で起り得る現象を再現している
と考えられる，本稿が，血栓の形成および成長 の機序を考えるうえで，読者にとって何らかの 参考になれば幸いである。

\section{参考文献}

1）田中健蔵: 血栓症の病理（村上元孝監修: 血栓症 一基礎と臨床一), ，日本メディカルセンター，東京, 1982, pp. $11 \sim 28$

2) Sato, M. and Ohshima, N.: Platelet thrombus induced in vivo by filtered light and fluorescent dye in mesenteric microvessels of the rat. Thromb. Res., $35:$ 319 334, 1984.

3）佐藤正明, 大島宣雄 : 微小血管内血小板血栓形成の 新しい実験モデルとその応用に関する 2,3 の基礎 的検討. $15: 36 \sim 44,1984$.

4) Sato, M., Natori, T. and Ohshima, N. : Effects of scavengers of active oxygens on the platelet thrombus formation in microvessels induced by photochemical reaction. Microcirc. Ann. 1987, pp. 135 136.

5) Rosenblum, W.I. : Biology of disease : Aspects of endothelial malfunction and function in cerebral microvessels. Lab. Invest., 55 : 252 268, 1986.

6) Sato, M. and Ohshima, N.: Velocity profiles of blood flow in microvessels measured by ten channels' dual-sensor method. Biorheology, 25 : $279 \sim 288,1988$.

7）佐藤正明, 大島宣雄: 1 ビット相関計を用いた TV 画像処理による微小血管内血流速度の計測. 医用電 子と生体工学, 19 : 45 48, 1981.

8) Sato, M. and Ohshima, N. : Effect of wall shear rate on thrombogenesis in microvessels of the rat mesentery. Circ. Res., 66 : 941 949, 1990.

9) Baker, M. and Wayland, H.: On-line volume flow rate and velocity profile measurement for blood in microvessels. Microvasc. Res., $7: 131$ 〜143, 1974.

10) Sato, M. and Ohshima, N.: Hemodynamics at stenoses formed by growing platelet thrombi in mesenteric microvasculature of rat. Microvasc. Res., 31 : 66〜76, 1986. 